\title{
弾性部の導入による産業用ロボットの協調作業への適用
}

\author{
大隅 久*1 新 井 民夫*2
}

\section{A Method for Introducing Industrial Robots to Cooperative Tasks}

\author{
Hisashi Osumi*1 and Tamio Arai*2
}

\begin{abstract}
This paper proposes a simple method for applying popular PID position-controlled industrial robots to cooperative tasks with force interactions among them. For handling single object by multiple robots, force control using torque controllers is generally used to avoid excessive inner forces, however, a popular industrial robot has a PID positioncontroller. Thus it is usually very difficult to realize cooperative control with industrial robots. This paper proposes a method to introduce flexible mechanisms at the tips of robots to control forces at the end-effectors. After the installation of flexible mechanisms at the tips of robots, a closed-loop structure including flexible parts is generated. First, the number of degrees of freedom of the closed-loop structure is analized by modeling the installed flexibility as virtual joint variables. Next, the minimum number of springs, required to avoid both excessive inner forces and vibrations caused by the installed flexibility, are derived. Finally, the minimum number of actuators to control the object in arbitrary directions of $3 \mathrm{D}$ space is derived for installed robots.
\end{abstract}

Key Words : Industrial Robot, PID Position Control, Flexible Mechanism, Closed Loop Mechanism, Virtual Joint Model

\section{1. 序論}

人間は 2 つ腕を利用することにより, 片方の腕だけでは持 ち上げることのできない重い荷物を持ち上げる，ビンの蓋を開 ける，物を持ち替えるといった様々な作業を行なう，ロボット においても複数で協調作業を行なうことにより，単体では不可 能な重量物ハンドリング，大型対象物のハンドリング等が可能 となる. また, 組付け対象と部品をそれぞれ別のロボットが把 持することで, 組立ラインの周辺装置を大幅に削減できるとい ったことが期待できる.

複数のマニピュレータが同一対象物をハンドリングする協調 作業では，対象物とそれを把持するマニピュレータが閉ループ 機構を構成する．このため, 各マニピュレータがそれぞれ位置 制御されると，誤差が発生した際に過大な内力が発生し，対象 物を落下，あるいは破損する恐れがある。このため協調作業を 実現するには，それぞれのマニピュレータ先端での力制御が必 要となる.

このため協調制御系の設計問題においては通常トルク制御系

原稿受付 1993 年 12 月 3 日

*1中央大学理工学部

*2 東京大学工学部

${ }^{* 1}$ Faculty of Science and Technology, Chuo University

${ }^{* 2}$ Faculty of Engineering, University of Tokyo
の利用を前提とし $[1]$, コンプライアンス制御を応用したもの [2][3]，ハイブリッド制御を利用したもの[4][5], 分解加 速度制御を利用したもの等 $[8]$ [11]が提案されている. しか し，一般に普及している既存の産業用ロボットでは関節の摩 擦, 減速機の存在等によりトルク制御が事実上不可能に近く, これまで提案されてきた研究の成果が市販の産業用ロボットで 実用化された例は非常に少ない. [3]では，それぞれのロボッ トに 1 型の制御系を構成しておき，コントローラに与える指令 值をセンサフィードバックにより修正することでロボットにコ ンプライアンスを与えている. しかし， ロボットの構造と対象 物の剛性が共に高い場合, 目標力の誤差を位置指令の修正で補 償するには制御サンプリングを極めて短くする必要がある。 ま た［6]では制御システムを並列処理により高速化することによ り，トルク制御ベースの協調制御を実現しているが，システム が大掛かりとなり汎用性を考えると実用的とは言い難い.

一方，産業用ロボットは自由空間での位置制御に関しては PID 位置制御系の利用により非常に高い性能を有しており， この特性を利用した協調制御手法を確立することは協調制御の 実用化のために非常に有効である. PID 位置制御系の利用を 前提とすると, 幾何的な変位により力を制御する必要性から, ロボットへの弾性部の導入が不可欠となる. [12]ではフォロワ ロボットの手先に導入されたカセンサが弾性部の役割となって 
おり，フォロワはたわみが 0 となるようフィードバック制御さ れている. [13]では，それぞれのロボット先端に機構的なコン プライアンスを導入し，速度制御系を利用した擬似的な加速度 制御によりロボットを制御することで，ロボット間の内力の変 動と物体の振動を制御する手法が提案されているが，実験は 1 自由度方向のみでしか行われていない. 弾性部のたわみを利用 して力を制御する場合には，たわみの量自体が制御対象とな り，機構の自由度を表す幾何的な変数として取扱う必要があ る.しかし，これまで弾性部のたわみを機構の自由度として利 用した研究は少ない[14][15].

本研究は，実用的な立場から産業用ロボットの協調作業への 利用を可能とするための手法を確立することを目的とする。ま ず，機構の持つ弾性部のたわみを自由度としてとらえるため, 機構の剛性行列から等価関節モデルを導出する手法を示す. 次 に位置制御系を有する 2 台の機構を協調可能とするために導入 の必要な弾性機構の条件, 弾性機構を内部に含む閉ループ機構 の自由度の算出手順，更に対象物を 6 方向に駆動できる条件を それぞれ明らかにする。この結果を用いて，剛性行列の既知な 一般の機構との協調に産業用ロボットを利用するための弾性機 構の配置方法, ロボットに必要となる自由度决定の指針を示 す．本研究の指針により，対象物に振動を生じることなく，し かも内力も過大とならない協調系が，位置制御系を有する産業 用ロボットにより簡単に実現可能となる.

\section{2. 弾性部のモデル化}

\section{1 等価関節モデル}

2 台の位置制御系を有するマニピュレータにより協調制御を 実現するためには，マニピュレータ間に弾性機構が存在しなけ ればならない，本章では，機構の弾性によるたわみを等価関節 としてモデル化する手順を示す.

一般に，機構の剛性はある方向には柔らかいがその他の方向 には固いといった方向性を有している，本論では柔らかい方向 に発生するたわみのみを弾性機構の自由度とみなし，このたわ みを仮想的な関節（以下等価関節と呼ぶ）とリンクにより表現 する．直感的には例えば Fig. 1(a )の平行板バネでは，等価関

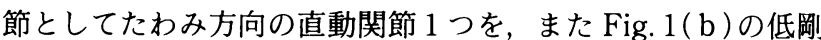

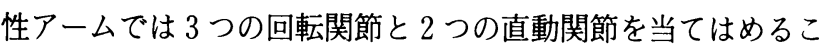

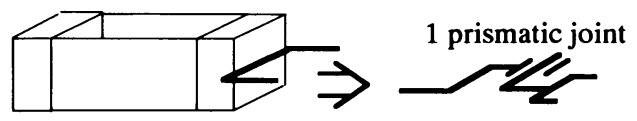

(a) Parallel beam

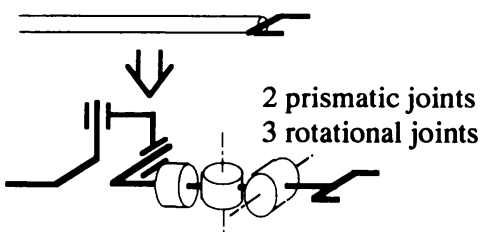

(b) Flexible arm
とができる.

\section{2 剛性行列に基づいた等価関節モデル迸出}

ある機構の 2 点間の剛性が，基準座標系において一般的な剛 性行列 $K \in R^{6 \times 6}$ で与えられたとする．Kは剛性行列なので実 対称行列であり，6つの直交する固有べクトル $\boldsymbol{u}_{i}(i=1 \sim 6)$ を 持つ. よってこれら 6 つの固有べクトルを列にもつ $6 \times 6$ の直 交行列 $U$ を用いることにより， $K$ を式(1)のように対角化す ることができる.

$$
U^{-1} K U=\Lambda=\operatorname{diag}\left(\begin{array}{llllll}
\lambda_{1} & \lambda_{2} & \lambda_{3} & \lambda_{4} & \lambda_{5} & \lambda_{6}
\end{array}\right)
$$

ただし $\lambda_{i}(i=1 \cdots 6)$ は $K$ の固有值である.

ここで剛性の定義された点に外力ベクトル $\boldsymbol{f}_{e}$ が加えられた とすると機構の変位 $\Delta x_{0}$ は

$$
\Delta \boldsymbol{x}_{0}=K^{-1} \boldsymbol{f}_{\boldsymbol{e}}
$$

となるので, 各固有ベクトル方向のたわみ $\Delta x_{i}$ を要素に持つ たわみべクトル $\Delta x_{d}$ は

$$
\begin{aligned}
\Delta \boldsymbol{x}_{d} & =U^{-1} \Delta \boldsymbol{x}_{0}=U^{-1} K_{c}^{-1} \boldsymbol{f}_{e} \\
& =\Lambda^{-1} U^{-1} \boldsymbol{f}_{e}
\end{aligned}
$$

となる.ここで

$$
\boldsymbol{f}_{t}=U^{-1} \boldsymbol{f}_{\boldsymbol{e}}
$$

ただし

$$
\boldsymbol{f}_{t}=\left[\begin{array}{llllll}
f_{t 1} & f_{t 2} & f_{t 3} & f_{t 4} & f_{t 5} & f_{t 6}
\end{array}\right]^{T}
$$

とすると， $f_{t i}$ は $\boldsymbol{u}_{i}$ 方向にかかる力の大きさを表しており，式 ( 3 )の各成分は

$$
\Delta x_{i}=\lambda_{i}^{-1} f_{t i}
$$

となる.つまり $\lambda_{i}$ は $\boldsymbol{u}_{i}$ 方向への剛性を表している. 従って, 固有値の大きさを調べることにより，機構の柔らかい方向，固 い方向が決定できる.

機構に力が作用すると，機構の固さに拘らず変位が発生す る.しかし，機構のたわみを積極的に自由度として利用する立 場からは，変位の大きさが非常に重要な意味を持つ。例えば Fig. 1（b ）に示した細長い棒の場合，引張り剛性と横方向の剛 性では引張り剛性の方が遙かに剛性が高い. 従って, “棒の先 端は横方向には動かせるが軸方向には動かすことができない” とみなすのが現実的である．以下の等価関節モデルの導出過程 においては，ある一定の固さを表現する值 $\lambda_{s}$ を基準として， 固有ベクトルを固い方向，柔らかい方向に分離する。

さて, $\lambda_{s}$ より小さい固有値を $\lambda_{f j}(j=1 . . m, m \leqq 6)$, 残りの固 有値を $\lambda_{r j}(j=1 . .6-m)$ とし，それぞれに対応した固有べクト ルを $\boldsymbol{v}_{f j}, \boldsymbol{v}_{r j}$ とする。 また $V_{f}, V_{r}$ を

$$
\begin{aligned}
V_{f} & =\left[\begin{array}{lll}
\boldsymbol{v}_{f 1} & \cdots & \boldsymbol{v}_{f m}
\end{array}\right] \\
V_{r} & =\left[\begin{array}{lll}
\boldsymbol{v}_{r 1} & \cdots & \boldsymbol{v}_{r(6-m)}
\end{array}\right]
\end{aligned}
$$

とし $V_{f}$ の縦ベクトルの張る空間 $S_{f}$ を弾性体空間， $V_{r}$ の縦べ クトルの張る空間 $S_{r}$ を剛体空間と定義する，なお， $\lambda_{s}$ はマニ ピュレータが発生できる最大力を加えた時に機構の発生する変 位と, 自由度として利用したい変位の大きさから決定すること ができる。

以上で一般の機構の持つ弾性体空間，剛体空間が求まった. 以下の議論では, 機構は弾性体空間の 1 組の直交基底方向 $\left(f_{m}\right.$ 次元)のみにそれぞれ弾性を有する $f_{m}$ 個のバネを有するものと 考える。

Fig. 1 Virtual joint and link 


\section{3. 位置制御系を有する機構間に必要な弾性機構}

2 台のマニピュレータのエンドイフェクタ間に位置決め誤差 が発生しても, エンドイフェクタ間に存在するバネのたわみに より誤差を吸収できれば過大な内力が発生することはない。し かし，バネを導入し過ぎると，外乱による振動や対象物の重力 によるバネのたわみにより，対象物に位置決め誤差が発生す る. それぞれのマニピュレータが位置制御系により制御されて も対象物に働く内力が過大とならず，しかもバネの導入に起因 した振動や位置決め誤差が発生しないバネの導入法は, 定理 1 にまとめることができる.

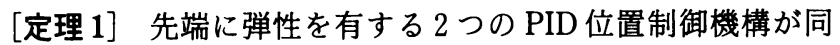
一対象物を把持点において自由度を残さず把持した系を考え る.この系において, (1) 機構間の相対的な位置決め誤差によ る内力の変動が過大とならず, (2) 対象物に任意の外力が作用 しても弾性に起因した対象物の位置・姿勢誤差が発生しない, ための必要十分条件は, 『1 次独立な方向に弾性を有する $6 \supset$ のバネが機構間に存在すること」である.

証明） 2 つのマニピュレータ間の相対位置决め誤差を $\Delta x_{e} \in$ $R^{6 \times 1}$ とする. また, バネが $n$ 本存在すると仮定し，このバネ の弾性方向の単位ベクトルをそれぞれ $\boldsymbol{s}_{i} \in R^{6 \times 1}(i=1 \sim n)$, バ ネの変位を $d_{i}(i=1 \cdots n)$ とする(Fig. 2). マニピュレータは 剛体なので，相対誤差 $\Delta x_{e}$ はバネのたわみのみによって夷現 されると仮定する. 従って式 (6)が成立つ.

$$
\begin{aligned}
& \Delta x_{e}=d_{1} \boldsymbol{s}_{1}+d_{2} \boldsymbol{s}_{2}+\cdots+d_{n} \boldsymbol{s}_{n} \\
& =\left[\begin{array}{llll}
\boldsymbol{s}_{1} & \boldsymbol{s}_{2} & \cdots & \boldsymbol{s}_{n}
\end{array}\right]\left[\begin{array}{llll}
d_{1} & d_{2} & \cdots & d_{n}
\end{array}\right]^{T} \\
& =S \boldsymbol{d}
\end{aligned}
$$

ただし

$$
\begin{aligned}
& S=\left[\begin{array}{llll}
\boldsymbol{s}_{1} & \boldsymbol{s}_{2} \cdots & \boldsymbol{s}_{n}
\end{array}\right] \\
& \boldsymbol{d}=\left[\begin{array}{llll}
d_{1} & d_{2} & \cdots & d_{n}
\end{array}\right]
\end{aligned}
$$

式 ( 6 ) より, 過大な内力が発生しない条件, すなわち任意の方 向の $\Delta x_{e}$ を実現することのできるバネのたわみ $d$ が存在する ためには， $S$ がフルランク，すなわち $n$ 個のバネの中に 6 つ の 1 次独立なバネの組が存在する必要がある. 逆に $S$ がフル ランクであれば, $d$ により任意の方向の $\Delta x_{e}$ が実現できる.

次に 1 次独立なバネが 6 つのみ存在する場合を考える.この 時, 式(1)の $S$ は $6 \times 6$ の正方行列となり $S^{-1}$ が存在する. 従 って, $d \in R^{6 \times 1}$ は

$$
\boldsymbol{d}=S^{-1} \Delta \boldsymbol{x}_{e}
$$

として, $\Delta x_{e}$ のみの関数として算出される. つまり，2つのマ ニピュレータの相対位置決め誤差が決定されると 6 つのバネの たわみも対象物に作用する力の大きさとは独立に一意に決定さ

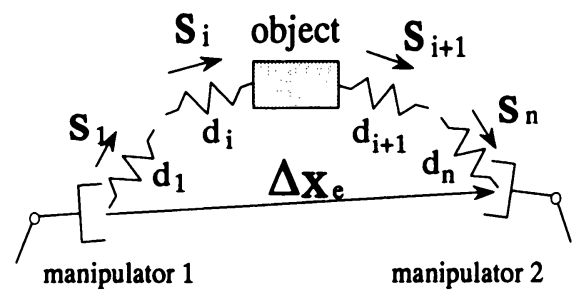

Fig. 2 Installation of linearly independent springs
れ，外力により与えられる拘束条件によってバネのたわみが変 化することはない.

(証明終わり)

以上の結果より，産業用ロボットを別の機構との協調制御に 利用するためには，ロボット先端と協調相手との間に 6 つの 1 次独立なバネが存在するよう，ロボット先端に弾性部を導入す ればよい. 2 章の結果より，協調相手の剛性解析によりバネを 求める. この結果得られるバネが $m$ 個で，それぞれ $\boldsymbol{v}_{f 1} \sim \boldsymbol{v}_{f m}$ 方向に存在したとすると， ロボット先端に導入するバネは $(6$ 一 $m$ ) 個となる. これらのバネが弾性を有する方向べクトルを それぞれ $\boldsymbol{a}_{1} \sim \boldsymbol{a}_{(6-m)}$ とすると，

$$
\operatorname{rank}\left(\left[\begin{array}{llllll}
v_{f 1} & \cdots & v_{f m} & a_{1} & \cdots & a_{(6-m)}
\end{array}\right]\right)=6
$$

となるようバネを導入すればよい.

\section{4. 弾性部を内部に含む閉ループ系の可動空間}

3 章において，位置制御系を有する機構間に必要となる弾性 機構の満たすべき条件を明らかにした.これらは位置決め剛性 無限大の機構間の相対位置詔差に起因する内力が過大とならな いための条件であったが，対象物の運動制御を 3 次元空間の 6 自由度方向で実現するためには対象物の可動空間が 6 となるた めの条件についての考察が必要となる.

本章では，協調相手となるマニピュレータと，これから導入 されるマニピュレータが有しているアクチュエータの持つ自由 度を考虑して，対象物の可動空間を算出する.

\section{1 幾何的拘束条件と力学的拘束条件}

閉ループ系の各関節, 等価関節に課せられる幾何的拘束条件 を導出するため, 一方のマニピュレータのベースをベース, 他 方のマニピュレータのベースを手先とするマニピュレータを考 える.この関節角べクトルの微小変位とマニピュレータ先端の 微小変位の関係を表すヤコビ行列を $J_{a} \in R^{6 \times(r 1+f 1+r 2+f 2)}$ とす る.ただし $r_{1}, r_{2}$ はそれぞれのマニピュレータの本来の関節数 を, $f_{1}, f_{2}$ は先端に付加された弾性機構の等価関節数である. マニピュレータ $A$ の先端はマニピュレータ 2 のベースである から，固定されている，従って式( 9 )が成立つ.

$$
J_{a} \Delta \boldsymbol{\theta}=0
$$

ただし

$$
\Delta \boldsymbol{\theta}=\left[\begin{array}{llll}
\boldsymbol{\theta}_{1}^{T} & \boldsymbol{\theta}_{f 1}^{T} & \boldsymbol{\theta}_{2}^{T} & \boldsymbol{\theta}_{f 2}^{T}
\end{array}\right]^{T}
$$

で, $\boldsymbol{\theta}_{i} \in R^{r i}, \boldsymbol{\theta}_{f i} \in R^{f i}$ はそれぞれマニピュレータ $i$ の本来の関 節角ベクトル，等価関節ベクトルを表す. 式 (9)が関節角べク トルの微小変位に課せられる幾何的拘束条件を表す式である. 一方等価関節の值は, 力の釣合を満たすようにしか実現できな い. Fig. 3 の例では，（a）の場合片方のマニピュレータの位置 を動かすことにより, バネの変位 $\Delta \theta_{2}$ を任意の值に設定でき る.これに対して(b)では，ばねは 2 つ存在するが $\Delta \theta_{2}$ と $\Delta \theta_{1}$ を独立に設定することができない. 即ち等価関節は 2 つるが 独立な関節は 1 つである.このような等価関節変数に課せられ る力学的拘束条件は, 両方のバネが共に弾性体として存在する 空間においてのみ必要となる. 重力場においてこの条件は式 (10)で表される.

$$
\begin{gathered}
H \Delta \boldsymbol{\theta}=P_{12} m \boldsymbol{g}^{\prime} \\
H=\left[\begin{array}{llll}
0 & P_{12} K_{1} V_{f 1} & 0 & P_{12} K_{2} V_{f 2}
\end{array}\right] \\
P_{12}=2 P_{f 1}\left(P_{f 1}+P_{f 2}\right)^{+} P_{f 2}
\end{gathered}
$$




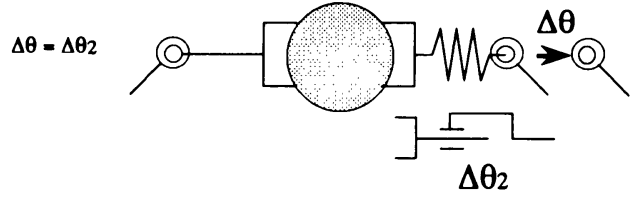

(a) without force constraint

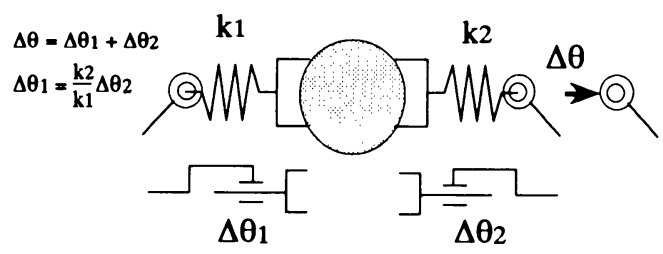

(b) with force constraint

Fig. 3 Force costraint

$$
P_{f i}=V_{f i} V_{f i}^{T}, \quad(i=1,2)
$$

式(10)は, 2 つの機構の弾性空間の交わりの空間において, 弾 性機構が発生する力と重力が釣り合うことを表している． $V_{f i}$ はマニピュレータ $i$ 側の弾性体空間の対象物座標系表示による 基底べクトルよりなる行列で， $P_{f i}$ はマニピュレー夕 $i$ の弾性 体空間への直交射影行列を表す。 $\boldsymbol{g}^{\prime}$ は重力加速度べクトルを 対象物座標系で表示したものである．また $P_{12}$ は対象物座標系 における $2 つ の$ 弾性体空間の交わりの空間への直交射影行列 で, $\left(P_{f 1}+P_{12}\right)^{+}$は $\left(P_{f 1}+P_{f 2}\right)$ の擬似逆行列を表す $[16]$. なお 定理 1 の条件が満たされている場合には $P_{12}=0$ となり, 式 (10) は不要となる.

\section{2 可動空間の算出法}

式（9），(10)で表される幾何的拘束条件，力学的拘束条件を まとめると

$$
W \Delta \boldsymbol{\theta}=\boldsymbol{C}
$$

ただし

$$
W=\left[\begin{array}{c}
J_{a} \\
H
\end{array}\right], \quad C=\left[\begin{array}{c}
0 \\
P_{12} m \boldsymbol{g}^{\prime}
\end{array}\right]
$$

となり，2つの拘束条件を満たしたまま発生し得る関節角空間 内の微小変位ベクトル $\Delta \boldsymbol{\theta}$ は

$$
\Delta \boldsymbol{\theta}=W^{+} C+P_{d} \boldsymbol{z}, \quad P_{d}=I-W^{+} W
$$

と表すことができる，ただし $\boldsymbol{z}$ は任意べクトルで， $W^{+}$は $W$ の擬似逆行列である. 式(12)の右辺第 1 項は重力により発生す る弾性部のたわみ, 即ち等価関節の変位を表し, 定理 1 が満た され $P_{12}=0$ となる場合には 0 となる. また定理 1 が満たされ ていない場合にもその值は現在の姿勢により一意に决定され る.これに対し第 2 項が関節角の制御により能動的に実現でき る微小移動べクトルを表す項である．即ち関節角空間の可動空 間 $S$ は $P_{d}$ の張る空間として，また閉ループ機構の自由度は $P_{d}$ のランクを調べることにより求まる. $P_{d}$ のランクを $d$ とす ると, $S$ の基底となり得る $\Delta \boldsymbol{\theta}$ の $d$ 個の要素の組を指定する ことにより，閉ループ機構の姿勢を一意に決定できる.

ここで関節角座標系と対象物座標系間のヤコビ行列を $J_{0}$ と すると, 対象物座標系の微小移動ベクトル $\Delta x_{0}$ は

$$
\Delta \boldsymbol{x}_{0}=J_{0} \Delta \boldsymbol{\theta}=J_{0} W^{+} \boldsymbol{C}+J_{0} P_{d} z
$$

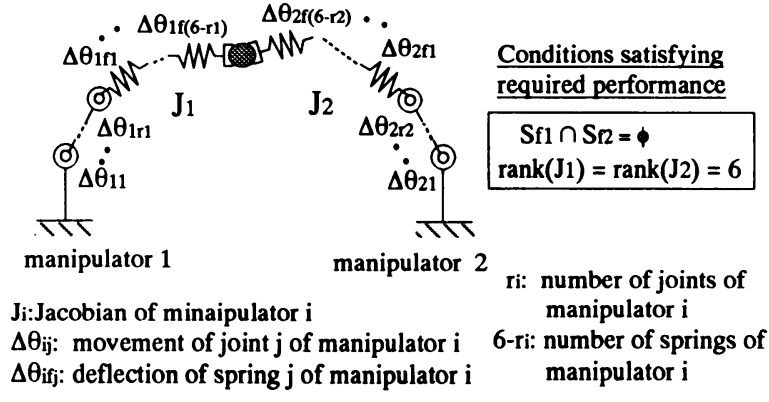

Fig. 4 Conditions satisfing required performance

となる。

以上より, 対象物座標系の可動空間は $J_{0} P_{d}$ の張る空間とし て求まる。このランクが 6 となれば対象物に任意の位置・姿勢 を取らせることが可能となる。

\section{3 可動空間が 6 となる機構的条件}

$J_{0} P_{d}$ のランクを 6 とすることのできる必要最小限の関節数 を機構的に考察すると，以下の定理 2 が導かれる.

[定理 2] 必要最小限の関節とバネで対象物の可動空間を 6 次 元とする必要十分条件は以下の(1)，(2)を同時に満たすことであ る.

(1) 各ロボットの等価関節を含めた機構的自由度がそれぞれ 6 で，ヤコビ行列のランクが 6 である.

(2) 各々のロボット先端の弾性機構同士が，共通の弾性体空間 を持たない.

証明)

十分）(1),(2)の条件が満たされていると，全 12 自由度には幾何 的な 6 つの拘束条件しか課せられないので，閉ループ機構の自 由度が 6 となる。つまり，6つの関節角値を設定すると残りの 6つの関節角值は一意に決る。この 6 つの関節角としてロボッ ト 1 の 6 関節を選ぶことができるのは(1)より明らかなので， ロ ボット 1 の先端, 即ち対象物の位置・姿勢 6 成分が任意に制御 できる.

必要）対象物を 6 方向に動かすための必要条件として(1)は明ら かである. (2)は力学拘束が存在しないことを意味している. 関 節角ベクトルの可動空間が幾何拘束, 力学拘束を共に満たす空 間であるから力学拘束は少ないほうが良い. 一方十分条件より 力学拘束が必要ないことは明らかであり, 必要最小限のバネで 実現するためには(2)が必要なことも明らかである.

（証明終わり）

この結果 (Fig. 4 参照)を利用すると, 例えば 3 自由度を有す る 2 つのマニピュレータの先に 3 つずつバネが付加されている ような場合にも，お互いのバネが共通空間を持っていなけれ ば，対象物を 6 自由度方向に動かすことが可能となる。

\section{5. 産業用ロボット導入の指針}

\section{1 産業用ロボット導入のための弾性機構の設計手順}

本章では，産業用ロボットを他の機構(以下協調相手と呼ぶ) と協調させて，対象物を 6 自由度方向に駆動するシステムを想 定する.これまで，3 章において 2 台の位置制御系を有する機 
構間に必要となるバネの条件，4 章において対象物の可動空間 を 6 とする条件を明らかにした．ここではこれらの結果をまと め, 導入する産業用ロボットとして必要最小限の自由度のもの を利用し協調を実現するための手順を示す.

手順は以下の通りである.

1）協調相手の機構の剛性を解析し，相手機構の有する弾性体 空間とその次元を求める.

2）協調相手の機構の剛体空間の次元の数だけ，ロボット先端 にバネを導入する．その際両方の弾性体空間の基底を合せた 6 つのベクトルが 6 次元空間の基底となるようにバネを配置 する.

3）ロボットに必要となる最低限の自由度が，ロボット先端に 導入する弾性機構のバネの数を 6 から引いた数として求ま る.

4）ロボットと弾性機構の等価関節を合せた 6 自由度が退化状 態とならないような関節配置となるようロボットの構造を決 定する.

1)〜4)の手順により, 最低限の自由度の産業用ロボットを用い て, 対象物に過大な内力をかけずしかも対象物に振動の発生し ない協調系が実現できる.

なお，本手法は弾性機構の変位も可動空間の基底として利用 しており，その可動範囲は考慮していない．即ち，対象物を動 かす空間は 6 次元であってもその領域はバネがたわみうる範囲 であることを前提としている．従って，対象物をバネのたわみ 量よりはるかに大きな範囲で動かす必要のある場合には，6つ のバネを確保した上で，更に，可動範囲の小さなバネの導入さ れた方向を可動方向とするアクチュエータをロボット側に追加 することが必要となる.

\section{2 平面内 2 次元空間の例}

Fig. 5 に, 平面内 2 次元空間において 2 台の 1 自由度マニピ ュレータにより質点の運動制御を行う例を示す.

左側のマニピュレータ 1 はアクチュエー夕を有する直動関節 と, 弾性を有する受動関節を持つ. 受動関節を含むこのマニピ ュレータのヤコビ行列は，受動関節を挟む 2 つのリンクが一直 線とならなければランクが 2 となる. 図では受動関節の角度が 45 度となっており,この条件が満たされている.この時, マ

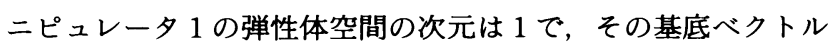
$v_{1}$ は対象物座標系において

$$
\boldsymbol{v}_{1}=\left[\begin{array}{ll}
1 / \sqrt{2} & -1 / \sqrt{2}
\end{array}\right]^{T}
$$

である.

これに対して，マニピュレータ1と協調するためのマニピュ レー夕 2 には $\boldsymbol{v}_{1}$ と一次独立な弾性体空間が必要となる。 この ような弾性体空間を持ち, 手先でのヤコビ行列が 2 となる機構 として Fig. 5 を考えることができる.この時のマニピュレー 夕 2 の弾性体空間の基底 $a_{1}$ は

となるので,

$$
\boldsymbol{a}_{1}=\left[\begin{array}{ll}
1 / \sqrt{2} & 1 / \sqrt{2}
\end{array}\right]^{T}
$$

$$
\operatorname{rank}\left(\left[\boldsymbol{v}_{1} \boldsymbol{a}_{1}\right]\right)=2
$$

となり, マニピュレータ 2 の手先でのヤコビ行列のランクが 2 となるのも明らかで, 定理 1)，2）の条件が満たされる，従っ

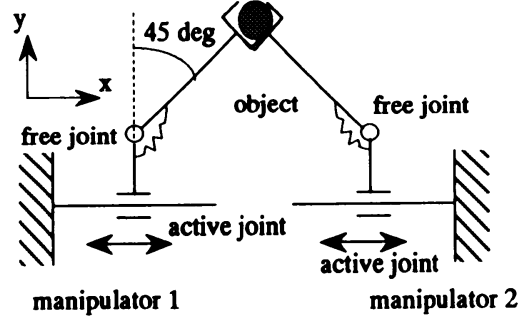

Fig. 5 Mechanical example in two dimensional space

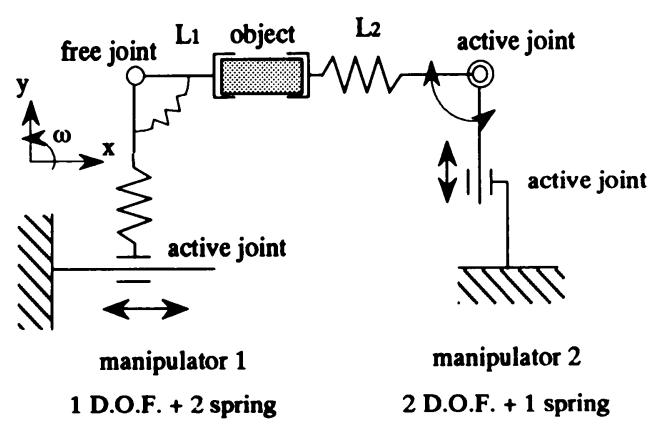

Fig. 6 Mechanical example in three dimensional space

てこの例では, マニピュレータ 1 もマニピュレータ 2 もクチ ュエータは共に $x$ 方向にしか存在しないにも拘らず，対象物 を 2 次元空間で駆動することができる.

\section{3 平面内 3 次元空間の例}

次に平面内 3 自由度空間の例をFig. 6 に示す.この例で は，マニピュレータ 1 の弾性空間は 2 次元で, 基底ベクトル $v_{11}, v_{12}$ として

$$
\begin{aligned}
\boldsymbol{v}_{11} & =\left[\begin{array}{lll}
0 & 1 & 0
\end{array}\right]^{T} \\
\boldsymbol{v}_{12} & =\alpha\left[\begin{array}{lll}
0 & L_{1} & 1
\end{array}\right]^{T}
\end{aligned}
$$

ただし

$$
\alpha=1 / \sqrt{\left(1+L_{1}^{2}\right)}
$$

を選ぶことができる. また, アクチュエー夕は $x$ 軸方向の直 動関節で，これに対応したヤコビ行列の綐ベクトル $\boldsymbol{j}_{1}$ は

$$
\boldsymbol{j}_{1}=\left[\begin{array}{lll}
1 & 0 & 0
\end{array}\right]^{T}
$$

となる. 従って, バネ 2 つを含むマニピュレータ 1 のヤコビ行 列 $\left[\begin{array}{lll}j_{1} & v_{11} & v_{12}\end{array}\right]$ のランクは 3 となる.

マニピュレータ 2 の弾性体空間 $\boldsymbol{a}_{1}$ は $x$ 軸方向のみで,

$$
\operatorname{rank}\left(\left[\begin{array}{lll}
v_{11} & v_{12} & a_{1}
\end{array}\right]\right)=3
$$

となるので内力が過大となることがない，また，マニピュレー 夕 2 のアクチュエー夕を有する関節は 2 つで，それぞれに対応 するヤコビ行列の縦ベクトル $j_{21}, j_{22}$ はそれぞれ

$$
\begin{aligned}
& j_{21}=\left[\begin{array}{lll}
0 & 1 & 0
\end{array}\right]^{T} \\
& j_{22}=\beta\left[\begin{array}{lll}
0 & -L_{2} & 1
\end{array}\right]^{T}, \quad \beta=1 / \sqrt{\left(1+L_{2}^{2}\right)}
\end{aligned}
$$

となる. よってマニピュレータ 2 のヤコビ行列 $\left[\begin{array}{lll}j_{21} & j_{22} & a_{2}\end{array}\right]$ のランクも 3 となるので, 定理 1),2)が満たされた.

これより，マニピュレータ 1 との協調に利用するためのマニ ピュレータとして 2 自由度のものとバネを 1 つ用意すればよい ことがわかる. 


\section{6. 結 論}

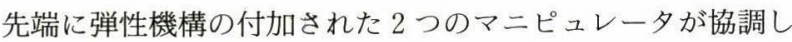
て同一対象物をハンドリングする際に構成される機構の運動学 的な解析を以下の手順により行なった

・PID 位置制御系を有する産業用ロボットの協調制御におい て, ロボット間の相対位置決め詋差が発生しても過大な内力 が発生せず，かつ対象物を外力に対して剛に保持するために は，6つの一次独立なバネを利用することが必要であること を示した。

•弹性機構の持つ剛性の方向性に着目し，機構の剛性行列を基 に位置・姿勢の 6 自由度方向を剛体空間，弾性体空間へ分離 した.

・弾性体空間に発生するたわみを等価関節変数によりモデル化 した.

- 等価関節変数を含む関節角空間に対し幾何的拘束条件, 力学 的拘束条件を共に満たす部分空間を算出する方法を示した.

これらの結果より,

1）弾性機構のたわみを考慮した協調系の機構的な自由度を明 らかにした。

2) 三次元空間の位置·姿勢 6 自由度方向全てに対して対象物の 運動が制御可能となる機構的条件を明らかにした。

3） PID 位置コントローラを有する一般的な産業用ロボットを 協調作業に利用するためのロボットの自由度，導入すべき弾 性機構の特性を示した。

\section{参 考 文 献}

[1] 小菅：“複数のマニピュレータによる協調制御”, 日本ロポット学会 誌, vol. 10, no. 4, pp. 13-17, 1992.

[2] 黑野: “一対の人工の手の協調制御”, Journal of the J. S. M. E., vol. 78 , no 682 , pp. $804-810$, Sept., 1975
［3］菅, 古賀, 古田, 野先：“仮想内部モデルに基づくロボットアームの 協調制御”, 計測自動制御学会論文集, vol. 27, no. 1, 93-100, 1991 .

[4] M. T. Mason: "Compliance and Force Control for Computer Controlled Manipulators," IEEE Trans. on System, Man and Cybernetics, vol. SMC-11, no. 6, 418-432, 1981.

[5] Uchiyama and Dauchez: "A Symmetric Hybrid Position/Force Control Scheme for the Coordination of Two Robots," Proc. of IEEE Int. Conf. on Robotics and Automation, pp. 350-356, 1988.

[6] N. Xi, T. J. Tarn and A. K. Bejczy: "Event-Based Planning and Control for Multi-robot Coordination," Proc. IEEE Int. Conf. on Robotics and Automation, pp. 251-258, 1993.

[ 7 ] C. D. Kopf and T. Yabuta: "Experimental Comparison of Master/Slave and Hybrid Two Arm Position/Force Control," Proc. IEEE Int. Conf. Robotics and Automation, pp. 1633-1637, 1988.

[8] 中村, 永井, 吉川: “複数のロボット機構による協調的あやつりの力 学”, 日本ロボット学会誌, vol. 5, no. 5, pp. 23-32, 1986.

[9] Tarn, Bejczy and Yun: "Design of dynamic Control of Two Cooperating Robot Arms Closed Chain Formulation," Proc. IEEE Int. Conf. Robotics and Automation, pp. 7-13, 1987.

[10] Zheng and Luh: "Optimal Load Distribution for Two Industrial Robots Handling a Single Object," Proc. IEEE Int. Conf. Robotics and Automation, pp. 344-349, 1988.

[11] M. Hashimoto and F. Oba: "Dynamic Control Approach for Motion Coordination of Multiple Wheeled Mobile Robots Transproting a Single Object," Proc. of IROS' 93, pp. 1944-1951, 1993.

[12] E. Nakano and S. Ozaki: "Cooperational Control of the Anthropomorphous Manipulator 'MELARM," Proc. 4 th Int. Symp. on Industrial Robots, pp. 251-260, 1974

[13] H. Osumi, T. Arai and E. Yoshida: "Cooperative Control between Multiple Manipulators with Flexibility," Proc. of IROS' 93, pp. 1935-1940, 1993.

[14] T. Arai and H. Osumi : "Construction System of Heavy Parts by the Coordinated control between a Crane and a Robot," Proc. 9 th Int. Symp. on Automation and Robotics in Construction, vol. 2, pp. 879-886, 1992.

[15]東, 酒田, 鈴木,伊東：“フレキシブルアームの伸縮動作特性”, 1993 年 度精密工学会春季大会予稿集, vol. 1, pp. 385-386, 1993.

[16] 柳井, 竹内: “射影行列・一般逆行列・特值分解”, 東京大学出版会, 1983.

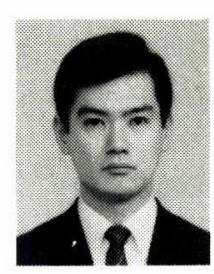

大隅 久 (Hisashi Osumi)

1962 年 3 月 5 日生. 1987 年東京大学大学院工学系 研究科精密機械工学専攻修士課程修了. 1988 年東 京大学工学部精密機械工学科助手. 1991 年同学科 講師. 1993 年同学科助教授. 1994 年中央大学理工 学部精密機械工学科助教授. ロボットの機講, 制 御に関する研究に従事. 精密工学会, 日本機械学 会, 計測自動制御学会, IEEE 会員. 工学博士.

（日本ロボット学会正会員）

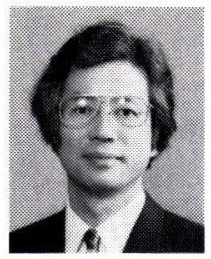

新井民夫（Tamio Arai）

1947 年 8 月 4 日生. 70 年東京大学工学部精密機械 工学科卒， 77 年同博士課程修了，工学博士． 87 年東 京大学工学部精密機械工学科教授. 79 年英国エデ インバラ大学人工知能学科研究員. 産業用ロボッ ト言語の標準化活動を推進. 自動組立, 移動ロボ ットなどの研究に従事. 精密工学会理事, 自動化 推進協会会長.

(日本ロボット学会正会員) 